American Journal of Environmental Sciences 8 (1): 71-78, 2012

ISSN 1553-345X

(C) 2012 Science Publications

\title{
Potential Environment and Public Health Risk Due to Contamination of Heavy Metals from Industrial Waste Water in Lam Thao, Phu Tho, Vietnam
}

\author{
${ }^{1}$ Nguyen Cong Vinh, ${ }^{2}$ Ingrid Oborn, ${ }^{3}$ Pham Quang Ha, \\ ${ }^{1}$ Ngo Duc Minh, ${ }^{4}$ Rupert Lloyd Hough, ${ }^{5}$ Nguyen Manh Khai and ${ }^{3}$ Le Thi Thuy \\ ${ }^{1}$ Soil and Fertilizer Research Institute, Hanoi, Vietnam \\ ${ }^{2}$ Swedish University of Agricultural Sciences, Uppsala, Sweden \\ ${ }^{3}$ Institute of Agricultural Environment, Hanoi, Vietnam \\ ${ }^{4}$ The James Hutton Institute, Aberdeen, UK \\ ${ }^{5}$ Environmental Faculty, Hanoi University of Science, Vietnam
}

\begin{abstract}
Problem statement: In Vietnam, rice cultivation plays an important role in national economic development and food security. However, rice production is facing many problems associated with rapid industrialization and urbanization in the country. Resultant emissions of solid and liquid wastes are often untreated and discharged directly to agricultural land. These practices have potential impacts on the environment and human health. Approach: The research was carried out within the frame of the collaborative research project "Towards the mitigation of environment and public health risks due to heavy metal contamination in irrigated rice-based systems of Vietnam" in 2006-2010. The study was implemented in the Lam Thao district, Phu Tho province with the aim to assess the effects of wastewater and other contamination sources on the environment and public health. Results: Surface water and soil in the field showed signs of significant contamination by wastewater from the industrial zones. Bio-indicators (DO, COD, BOD5) in the surface water were also strongly affected by waste. Paddy fields around the industrial zones had an elevated risk of heavy metal contamination $(\mathrm{Cu}, \mathrm{Zn}$, As, $\mathrm{Cd}$ and $\mathrm{Pb})$, with concentrations exceeding Vietnamese Maximum Acceptable Concentrations (MACs) for $\mathrm{Cu}, \mathrm{Zn}, \mathrm{Cd}$ and $\mathrm{Pb}$. Soil contamination with heavy metals was resulting in elevated concentrations in rice grain. Where consumption of locally-produced food was high, exposure of individuals to heavy metals could present a public health risk. The partial Hazard Quotient (HQ; a ratio derived from comparing estimated exposure to heavy metals, i.e., Cd, (with toxicologically-derived, safe' daily doses) for rice and vegetables (water spinach) and the integrated Hazard Quotient of rice and vegetables (HQi) was consistently greater in areas with soil contamination than in the reference area using Red River water for irrigation. The HQi for Cd was particularly high for children below the age of 13 and it was slightly higher for females than for males. While toxicologically-derived 'safe' daily doses are very conservative to account for inherent uncertainty in their derivation, this issue should be raised with famers and policy makers. Conclusion/Recommendations: Due to unrestricted discharge of industrial waste, the soil and water environment has been contaminated, which is demonstrated by accumulation of heavy metals in surface soils. This may in some circumstances pose a risk to public health. Policies should be developed that enable authorities to mitigate negative environmental impacts of industry and empowers communities to nurture a safer environment whilst maintaining the economic benefits of development.
\end{abstract}

Key words: Environmental pollution, health risk, paddy rice, agricultural land, food frequency, surface water, industrial waste water, red river delta, food production, rice production

\section{INTRODUCTION}

The Red River Delta is comprised of 11 provinces and cities, covering on an area of $1479416 \mathrm{~h}$. (4.5\% of the country) with apopulation of 17648700 (22\% of the total population of Vietnam, in 2003). Agriculture, the primary industry, is a significant proportion of the economy in the Red River Delta with 1.2 $\mathrm{M}$ h used for food production, which corresponds to $14 \%$ of the agricultural land area in Vietnam. In 1999, food

Corresponding Author: Nguyen Cong Vinh, Soil and Fertilizer Research Institute, Hanoi, Vietnam 
Am. J. Environ. Sci., 8 (1): 71-78, 2012

production in the Red River Delta was reported as being $6.1 \mathrm{Mt}$ (18\% of food production in Vietnam. The economy of the Red River Delta is also reliant on so called "trade villages" whose populations are involved in various cottage industries producing goods for market (furniture, clothes, ceramics) as well as recycling materials such as metal scrap for sale to larger industry. The Red River Delta has the largest density of trade villages in Vietnam (472 reported in 2004), but there are also some more large scale industrial zones.

Rice production is the dominant primary industry. However, rice production is facing many problems, due to rapid industrialization, urbanization and modernization in rural areas. In recent times, waste disposal has been relatively un-restricted leading to significant environmental pollution. For example, thousands of trade villages release huge volumes of water and solid wastes, as well as air emissions. In the majority of circumstances, these wastes are applied directly to agricultural land without any form of treatment. This has impacts on the environment and implications for public health. In many developing countries, there is a growing awareness of the potential for food production systems to become contaminated with heavy metals through rapid industrialization and urbanization. There is, however, very little evidence that heavy metal contamination, e.g., of soils, water and food crops, is a generic problem in South East Asia.

In this study we investigated potential links between the discharge of wastewater and the contamination of the food chain. To achieve this, samples of soils and food crops (rice and vegetables) were taken from agricultural land at a specific study community and analyzed for heavy metals. Questionnaire tools were used to estimate consumption of various foods and hence estimate exposure to heavy metals.

\section{MATERIALS AND METHODS}

Study site: The study site is located in Thach Son commune, Lam Thao district, Red River Delta, Northern Vietnam. There are a phosphate fertilizer factory and a chemical company in the vicinity. Thach Son commune has 155 ha agricultural land for rice-rice, 15 ha for ricerice-vegetable and 60 ha for perennial crops. The soils in the area are alluvial soils (Eutric Fluvisols) formed in material deposited by the Red River.

According to Ministry of Natural Resources and Environment (MONRE, 2006) there are 15 industrial factories in Lam Thao commune and thousands of industrial factories around Phu Tho province with the potential to produce undesirable wastes. Wastewater from processes that are potential sources of contamination tends to be applied directly to the agricultural land.

Methods: Soil survey and sampling was carried out during harvesting time in Spring 2007. Transects were established in representative fields known to be influenced by various potential sources of contamination. Paired soil $(0-20 \mathrm{~cm}$ depth $)$ and rice samples were taken at fixed points along each transect $(\mathrm{n}=15)$. Each soil sample was a composite of 5-7 sub samples mixed to a bulk sample. Non wastewater affected soils (reference) were also sampled for comparison $(n=15)$. Associated rice samples (Oryza sativer $\mathrm{L} ; \mathrm{n}=30$ ) comprised a composite made up of grain samples taken randomly from 15-20 rice hills. Vegetable samples (water spinach, Impomoea aquatic $\mathrm{L} ; \mathrm{n}=10$ ) were taken in the fields around the commune where they were known to be affected by wastewater and where they were not. Only the edible portion of the vegetables was retained for analyses. Rice and vegetable samples were initially rinsed in tap water, washed with distilled water, air dried in the shade, then oven dried at $60-65^{\circ} \mathrm{C}$.

Surface water samples $(n=7$ from contaminated and $n=5$ from reference site) were taken from the canals into which wastewater from factories is discharged; but also from paddy fields where wastewater was used for irrigation. As reference, surface water was sampled in fields irrigated with Red River water. Each water sample was taken in a 500 $\mathrm{mL}$ plastic bottle. Dissolved Oxygen (DO), $\mathrm{pH}$ and EC were determined on arrival to the lab. Water samples were kept in the freezer $\left(-2^{\circ} \mathrm{C}\right)$ no longer than 2 days prior to analyses of bio-indicators; Chemical Oxygen Demand (COD) and Biological Oxygen Demand during decomposition occurring over a 5-day period (BOD5), (Eaton et al., 1995).

Methods for soil extractions and analyses: $\mathrm{pH}, \mathrm{EC}$, Organic Carbon (OC), ammonium acetate extractable cations $\left(\mathrm{Na}^{+}, \mathrm{K}^{+}, \mathrm{Ca}^{2+}, \mathrm{Mg}^{2+}\right)$ and CEC in soil and EC and $\mathrm{pH}$ in water was carried out according to the Australian laboratory hand book, (Rayment and Higginson, 1992). $\mathrm{Cd}, \mathrm{Zn}, \mathrm{Cu}, \mathrm{Pb}$ and $\mathrm{As}$ in soil were digested by reverse aqua regia extraction $\left(3 \mathrm{HNO}_{3}: 1\right.$ $\mathrm{HCl}$; Stevens et al., 2003). BOD5, DO and COD in water were determined following the guideline of Vietnamese standards (TCVN 6001-1995; TCVN 73252004). Rice grain (unpolished) and vegetables were wet digested with concentrated $(10+5 \mathrm{~mL}) \mathrm{HNO}_{3}$ at $135^{\circ} \mathrm{C}$ (17h using digestion block). Metal concentrations were determined by inductively coupled plasma mass spectrometry (ICP-MS, Perkin Elmer ELAN 6100) (Stevens et al., 2003). 
Food frequency questionnaire: daily food consumption for each person in the study population (n $=126$ in the contaminated area and $n=122$ in the reference area) was obtained by direct individual interview with each person in each family. The body weight and height was measured during the interview.

The exposure Related Dose Estimating Model (Erdem) for Assessing Human Exposure and Dose was used to calculate the Average Daily Dose (ADD, mg $\mathrm{kg}^{-1} \mathrm{~d}$ ) for each study participant for $\mathrm{Cd}$ (e.g., Hough et al., 2004). Estimates of ADD were compared to" safe doses" published in the literature. Safe doses are primarily derived from toxicological data and provide an estimation of daily dose $\left(\mathrm{mg} \mathrm{kg}^{-1} \mathrm{~d}\right)$ that will not result in deleterious effects during a lifetime. In this study, Reference Doses (RfD, $\mathrm{mg} \mathrm{kg}^{-1} \mathrm{~d}$ ) published by the USEPA (1997) were used as "safe doses". The ratio of ADD to a safe dose is often termed the Hazard Quotient (HQ) for a single substance and Hazard Index (HI) for multiple substances and/or exposure pathways. Where a value of HQ for an individual exceeds unity, their ADD has exceeded the safe dose. This indicates the potential for that individual to experience deleterious health effects, resulting from the exposure of concern, at some point during their lifetime (USEPA, 1989)

\section{RESULTS}

Surface water as affected by contamination: Surface water samples were taken from the canal outlet which runs from the waste pond of Lam Thao phosphate fertilizer and chemical factory and from other canals in which wastewater drains to the Red River (Fig. 1). The Electrical Conductivity (EC) ranged from 0.2-3.9 $\mu \mathrm{S}$ $\mathrm{cm}^{-1}$ in the wastewater canals and irrigated fields compared to $0.2-0.3 \mu \mathrm{S} \mathrm{cm} \mathrm{cm}^{-1}$ in the reference field irrigated by Red River water (Fig. 1).

The $\mathrm{pH}$ values of the surface water samples from the contaminated area were in the range from 2.3-7.9 (mean 6.8) (Fig. 1). In the reference area, the $\mathrm{pH}$ values in the surface water ranged from 6.8-9.0 (mean 7.7).

Bio-indicators in water: The content of Dissolved Oxygen (DO) ranged from $0.7-7.2 \mathrm{mg} \mathrm{O} / \mathrm{L}$ (mean 5.3 mg O/L) (Table 1).

The Biological Oxygen Demand during decomposition occurring over a 5-day period (BOD5) ranged from 2.1-6.9 (mean $4.3 \mathrm{mg} \mathrm{O/L}$ ). (Table 1).

Soil chemical properties as affected by different contaminant sources: Measured chemical properties of the soil samples are presented in Table 2 and 3 The Electrical Conductivity (EC) ranged from 0.13-0.39 $\mu \mathrm{S}$ $\mathrm{cm}^{-1}$ for the wastewater irrigated soils and from 0.09$0.39 \mu \mathrm{S} \mathrm{cm}^{-1}$ for the reference soils. The $\mathrm{pH}_{\mathrm{KCl}}$ and
$\mathrm{pH}_{\mathrm{H} 2 \mathrm{O}}$ values in the wastewater irrigated soils ranged from 5.0-7.6 (mean 6.7) and 5.6-8.0 (mean 7.2), respectively and in the reference soils the corresponding $\mathrm{pH}$ values were 4.7-7.9 (mean 6.8) and 4.1-7.7 (mean 6.2) (Table 2). Variability of soil Organic Carbon (OC) content measurements in top soil samples was large and the concentrations were higher in the wastewater irrigated soils than in the reference soils, 1.7-3.2\% OC (mean 2.2) in the wastewater irrigated soils and $0.5-2.5 \%$ OC (mean 1.6) in the reference soils (Table 2).

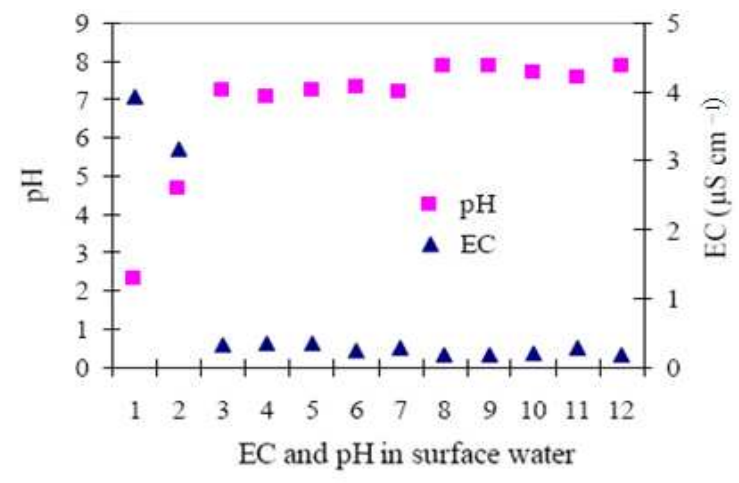

Fig. 1: $\mathrm{pH}$ and conductivity in surface water sampled in a gradient from the outlet (no 1) and further out over the paddy fields (no 2-7) as compared to reference sites where Red River water is used for irrigation (no 8-12)

Table 1: Bio-indicators in surface water

\begin{tabular}{lccr}
\hline & \multicolumn{2}{c}{ Thach son, lam thao $\left(\mathrm{mg} \mathrm{L}^{-1}\right)$} & \\
index & - & CO & DBOD5 \\
\hline Min & DO & 10.20 & 2.10 \\
Max & 0.68 & 61.00 & 6.90 \\
Average & 7.19 & 26.61 & 4.30 \\
Stdev & 5.29 & 16.11 & 1.56 \\
CV\% & 1.90 & 60.50 & 36.20 \\
VN.Sta. A $(*)$ & 36.00 & $<10.00$ & $<4.00$ \\
\hline
\end{tabular}

*: Vietnamese standard No. QCVN 08:2008/BTNMTa

Table 2: Soil analyses of Electrical Conductivity (EC), pH and Organic Carbon (OC) in Lam Thao

Wastewater irrigated soils

\begin{tabular}{lcccc} 
& & $\mathrm{pH}(1: 5)$ & \\
Statistical & $\mathrm{EC}(1: 5)$ & $-\mathrm{KCl}^{-1}$ & $\mathrm{OC}(\%)$ \\
index & $\left(\mu \mathrm{S} \mathrm{cm}^{-1}\right)$ & $\mathrm{H}_{2} \mathrm{O}$ & $\mathrm{K}$ & \\
\hline Min & 0.127 & 5.64 & 5.02 & 1.69 \\
Max & 0.387 & 8.05 & 7.59 & 3.20 \\
Average & 0.250 & 7.24 & 6.73 & 2.25 \\
Stdev & 0.093 & 0.61 & 0.65 & 0.44 \\
Reference soils & & & & \\
Min & 0.094 & 4.68 & 4.12 & 0.47 \\
Max & 0.388 & 7.87 & 7.70 & 2.45 \\
Average & 0.178 & 6.77 & 6.21 & 1.62 \\
Stdev & 0.090 & 1.24 & 1.29 & 0.68 \\
\hline
\end{tabular}


Am. J. Environ. Sci., 8 (1): 71-78, 2012

Table 3: Soil chemical properties in wastewater irrigated and reference soils in Lam Thao

\begin{tabular}{|c|c|c|c|c|c|}
\hline \multirow{3}{*}{$\begin{array}{l}\text { Statistical } \\
\text { index }\end{array}$} & \multicolumn{5}{|c|}{ Exchangeable cations (meq/100 g soil) } \\
\hline & \multicolumn{4}{|c|}{ Wastewater irrigated soils } & \multirow[b]{2}{*}{ CEC } \\
\hline & $\mathrm{Na}^{+}$ & $\mathrm{K}^{+}$ & $\mathrm{Ca}^{2+}$ & $\mathrm{Mg}^{2+}$ & \\
\hline Min & 0.14 & 0.09 & 11.1 & 4.9 & 18.4 \\
\hline Max & 0.34 & 0.23 & 15.8 & 8.2 & 23.2 \\
\hline Average & 0.20 & 0.14 & 13.1 & 6.2 & 21.1 \\
\hline Stdev & 0.07 & 0.04 & 1.2 & 1.0 & 1.3 \\
\hline \multicolumn{6}{|c|}{ Reference soils } \\
\hline Min & 0.03 & 0.04 & 4.8 & 1.6 & 9.5 \\
\hline Max & 0.22 & 0.22 & 15.0 & 3.7 & 20.4 \\
\hline Average & 0.12 & 0.11 & 10.6 & 3.7 & 16.3 \\
\hline Stdev & 0.05 & 0.05 & 3.6 & 1.6 & 4.2 \\
\hline
\end{tabular}

Table 4: Heavy metals in soil in wastewater irrigated and reference soils in Lam Thao $\left(\mathrm{mg} \mathrm{kg}^{-1}\right.$ soil)

\begin{tabular}{lrrrrr}
\hline & \multicolumn{4}{l}{ Wastewater irrigated soils } & \\
Statistical index & \multicolumn{1}{c}{ Cu } & \multicolumn{1}{c}{ Zn } & \multicolumn{1}{c}{ As } & \multicolumn{1}{c}{ Cd } & \multicolumn{1}{c}{ Pb } \\
\hline Min & 26.7 & 90.00 & 5.60 & 0.195 & 39.20 \\
Max & 204.0 & 713.60 & 52.30 & 1.536 & 140.00 \\
Average & 82.3 & 244.80 & 19.60 & 0.624 & 72.20 \\
Stdev & 47.1 & 172.10 & 11.20 & 0.375 & 27.30 \\
CV\% & 57.3 & 70.30 & 57.40 & 60.100 & 37.90 \\
Reference soils & & & & & \\
Min & 12.1 & 27.50 & 2.60 & 0.093 & 17.600 \\
Max & 92.3 & 165.00 & 52.90 & 0.624 & 138.000 \\
Average & 37.1 & 80.90 & 15.10 & 0.254 & 51.200 \\
Stdev & 23.9 & 36.90 & 15.30 & 0.158 & 37.800 \\
CV\% & 64.5 & 45.70 & 101.00 & 62.200 & 73.900 \\
VN.stad (*) & 50.0 & 20.00 & 23.00 & 2.000 & 70.000 \\
\hline
\end{tabular}

Note *: VN standard No QCVN 03:2008/BTNMTb

Exchangeable cations and the Cation Exchange Capacity (CEC) of the surface soils are presented in Table 3. Alkaline cations $\left(\mathrm{Na}^{+}, \mathrm{K}^{+}\right)$and earth alkaline cations $\left(\mathrm{Ca}^{2+}, \mathrm{Mg}^{2+}\right)$ in soil samples from the wastewater irrigated sites were mostly elevated compared to the reference sites.

The total cation Exchange Capacity (CEC) was also higher in the wastewater irrigated soils which can be linked to the higher organic carbon content.

Heavy metal accumulation in the soil as affected wastewater: Accumulation of heavy metals in the soil is affected by wastewater (Table 4).

The concentrations of reverse aqua regia extractable heavy metals $(\mathrm{Cu}, \mathrm{Zn}, \mathrm{As}, \mathrm{Cd}$ and $\mathrm{Pb})$ measured in the samples from the wastewater irrigated soils were significantly higher than concentrations measured in reference soils.

Heavy metal accumulation in rice as affected by wastewater: The total concentrations of heavy metals $(\mathrm{Cu}, \mathrm{Zn}, \mathrm{As}, \mathrm{Cd}$ and $\mathrm{Pb})$ measured in unpolished rice at the study sites is shown in Table 5 .
Table 5: Heavy metals in unpolished (husked) rice grown in wastewater irrigated and reference soils in Lam Thao ( $\mathrm{mg}$ $\mathrm{kg}^{-1}$ dry weight)

\begin{tabular}{lrrrrr}
\hline \multirow{5}{*}{$\begin{array}{l}\text { Statistical } \\
\text { index }\end{array}$} & \multicolumn{1}{c}{ Wastewater irrigated soils } & & \\
\cline { 2 - 6 } Min & \multicolumn{1}{c}{ Cu } & \multicolumn{1}{c}{ Zn } & \multicolumn{1}{c}{ As } & \multicolumn{1}{c}{ Cd } & \multicolumn{1}{c}{$\mathrm{Pb}$} \\
Max & 0.93 & 0.46 & 0.07 & 0.01 & 0.11 \\
Average & 4.23 & 28.20 & 0.65 & 0.78 & 0.64 \\
Stdev & 2.55 & 17.50 & 0.26 & 0.13 & 0.16 \\
CV\% & 1.01 & 4.34 & 0.18 & 0.23 & 0.13 \\
Reference soils & 39.40 & 24.90 & 72.10 & 179.00 & 81.60 \\
Min & & & & & \\
Max & 0.91 & 16.40 & 0.13 & 0.01 & 0.10 \\
Average & 3.88 & 23.30 & 0.47 & 0.09 & 0.22 \\
Stdev & 2.35 & 19.10 & 0.22 & 0.03 & 0.13 \\
CV\% & 1.20 & 2.17 & 0.11 & 0.03 & 0.04 \\
& 51.20 & 11.40 & 47.30 & 111.00 & 27.40 \\
\hline
\end{tabular}

Table 6: Total Cd content in unpolished (husked) rice and waterspinach, $\left(\mathrm{mg} \mathrm{kg}^{-1} \mathrm{DW}\right)$

\begin{tabular}{lll}
\hline Food & Situation & Mean value $(\mathrm{St} \pm$ Dev $)$ \\
\hline Rice & Contamination & $0.0580( \pm 0.027)$ \\
Water & Reference & $0.0240( \pm 0.015)$ \\
Spinach & Contamination & $0.0406( \pm 0.016)$ \\
\hline
\end{tabular}

Accumulation of heavy metals in unpolished rice on the contaminated soils tends to be higher than that in rice grown in reference soils, particularly Cd (Table 5).

Exposure to cadmium to populations living in Thach Son, Lam Thao: Heavy metals can be absorbed and accumulate in the body through the ingestion of contaminated food. Rice and water spinach are the main crops produced from local lands. Consumption of these crops and levels of $\mathrm{Cd}$ that they contain were used to estimate the potential publish health risk to local inhabitants. To obtain the absorbed daily dose of $\mathrm{Cd}$, concentrations of $\mathrm{Cd}$ in rice and water spinach was analyzed. Total rice and water spinach consumption was obtained from the food frequency questionnaire. The $\mathrm{Cd}$ concentrations measured in rice field belonging to the household orgrown on plots adjacent to the household was used in the calculations. Cadmium accumulation in husked rice and water spinach in the households in reference area was significantly lower than in the contaminated area (Table 6). In order to estimate risks to specific population sub-groups (age, gender, socio- economic status), self- reported questionnaire data were used to link measured concentrations of heavy metals to exposure via contact with soils, the environment and through daily consumption of rice and vegetables. Participants were interviewed during a household survey. Interviewees provided details of all the residents of their household. During the interview, participants identified fields from which food supplies, including rice were grown. Water spinach was sampled in the study villages. 
Am. J. Environ. Sci., 8 (1): 71-78, 2012

Table 7: Ingestion Rate per unit time (IR) in people in thach son commune, lam thao district

\begin{tabular}{|c|c|c|c|c|}
\hline \multirow{3}{*}{$\begin{array}{l}\text { Statistical } \\
\text { index }\end{array}$} & \multicolumn{4}{|c|}{ Average of $g$ food consumption, ( $\mathrm{g}$ dry w/day/person) } \\
\hline & \multicolumn{2}{|c|}{ Contaminant area } & \multicolumn{2}{|c|}{ Reference area } \\
\hline & Rice & Water spi. & Rice & Water spi. \\
\hline $\mathrm{n}^{*}$ & 126 & 109.0 & 122.0 & 111.0 \\
\hline Min & 50 & 11.0 & 42.0 & 15.0 \\
\hline Max & 940 & 471.0 & 910.0 & 600.0 \\
\hline Average & 398 & 121.0 & 385.0 & 126.0 \\
\hline St.Dev & 178 & 93.2 & 181.8 & 98.7 \\
\hline
\end{tabular}

The concentration of $\mathrm{Cd}$ in rice and vegetables were used to estimate the daily Intake Rate (IR) of Cd and the Hazard Quotient (HQ) (Table 7). Estimated values of the Average Daily Dose (ADD; $\mathrm{mg} \mathrm{kg}^{-1} \mathrm{~d}$ ) of each study participant are presented in Table 8 . In the contaminated areas, consumption of rice ranges from 50-940 g dry weight/person/day and 1-471 g dry weight/person/day for water spinach (Table 7). In the reference area, consumption of rice was estimated as being 42-910 g dry weight/person/day and 15-600 g dry weight/person/day for water spinach (Table 7).

Based on the ingestion rate (Table 7), body weight and $\mathrm{Cd}$ concentration in rice and water spinach samples; daily dose of intake of $\mathrm{Cd}$ by humans was calculated using Eq. 1:

$$
\mathrm{ADD}=\frac{\mathrm{Cx} \mathrm{IR} \times \mathrm{EF} \times \mathrm{ED}}{\mathrm{WB} \times \mathrm{AT}}
$$

Where:

$\mathrm{C}=$ Contamination concentration in media $\left(\mathrm{mg} \mathrm{kg}^{-1}\right)$

$\mathrm{IR}=$ Ingestion rate per unit time or event $\left(\mathrm{kg} \mathrm{day}^{-1}\right)$

$\mathrm{EF}=$ Exposure frequency (days/year)

$\mathrm{ED}=$ Exposure duration (years) is the length of time that a receptor is exposed via a specific exposure pathway

$\mathrm{BW}=$ Body weight of receptor over the exposure period $(\mathrm{kg})$

AT $=$ Average time- the period over which exposure is averaged (days)

Since this study involves non-carcinogens or noncancer toxic risk, $\mathrm{EF}=365$ days $* \mathrm{AT}=\mathrm{ED} * 365$ (USEPA,1989; 1997). Results are presented in Table 8. The Average Daily Dose (ADD; $\mathrm{mg} \mathrm{kg}^{-1} \mathrm{~d}$ ) of Cd was estimated as the measured concentration of $\mathrm{Cd}$ in the food crop samples (expressed as fresh weight) multiplied by the amount of that food ingested.

Estimates of ADD for study participants from the contaminated site were significantly elevated when compared to equivalent measures at the reference site.
Table 8: Average Daily Dose (ADD) in the thach son commune population

\begin{tabular}{lll}
\multicolumn{3}{c}{ mopulation } \\
& mg Cd kg ${ }^{-1}$ BW/day & \\
\cline { 2 - 3 } Statistical & Contaminant area & \\
index & Rice & Water spi. \\
\hline $\mathrm{n}^{*}$ & 126 & 109 \\
Min & $7.42 \mathrm{E}-05$ & $8.37 \mathrm{E}-06$ \\
Max & $2.33 \mathrm{E}-03$ & $5.63 \mathrm{E}-04$ \\
Ave. & $6.92 \mathrm{E}-04$ & $1.09 \mathrm{E}-04$ \\
St.Dev & $4.94 \mathrm{E}-04$ & $8.49 \mathrm{E}-05$ \\
Reference area & & \\
$n^{*} n^{*}$ & 122 & 111 \\
Min & $3.96 \mathrm{E}-05$ & $5.88 \mathrm{E}-07$ \\
Max & $1.70 \mathrm{E}-03$ & $3.66 \mathrm{E}-04$ \\
Ave. & $3.80 \mathrm{E}-04$ & $1.01 \mathrm{E}-04$ \\
St.Dev & $3.49 \mathrm{E}-04$ & $8.04 \mathrm{E}-05$ \\
\hline
\end{tabular}

$\mathrm{n}$ *: The number of interviewed people who ate rice and water spinach the day before the interview.

Table 9: Hazard Quotient (HQ) in the THACH SON commune

\begin{tabular}{lrr}
\hline & Contaminant area & \\
Statistical & HQ rice & Water spinach \\
index & 122.00 & 109.00 \\
\hline n* & 0.10 & 0.01 \\
Min & 1.99 & 0.56 \\
Max & 0.61 & 0.11 \\
Ave. & 0.31 & 0.08 \\
St.Dev & & \\
Background area & 126.00 & 111.00 \\
n* & 0.03 & 0.01 \\
Min & 0.76 & 0.37 \\
Max & 0.36 & 0.10 \\
Ave. & 0.14 & 0.08 \\
St.Dev & & \\
n*: The number of interviewed people who ate rice and spinach the \\
day before the interview.
\end{tabular}

Risk' was expressed in terms of a Hazard Quotient (HQ) which was calculated by Eq. 2:

$$
\mathrm{HQ}=\frac{\mathrm{ADD}}{\mathrm{RfD}}
$$

where, Reference dose ( $\mathrm{mg} \mathrm{kg}^{-1}$ day) RfD is defined as the maximum tolerable daily intake of a specific metal that will not cause a health risk. The RfD value for Cd in food: $0.001 \mathrm{mg} \mathrm{kg}^{-1}$ day (USEPA, 1997). If ADD exceeds the RfD, HQ $>1$; this suggests there is a probability of experiencing deleterious health outcomes associated with Cd. If ADD is less than the RfD, HQ $<1$ : this suggests the probability of experiencing deleterious heath outcomes associated with $\mathrm{Cd}$ is unlikely (USEPA, 1997). Food-specific partial HQ:s were estimated as being 0.10-1.99 (mean 0.61) for rice and 0.01-0.56 (mean 0.11) for water spinach (Table 9) for people living in the contaminated area. In the reference area, HQ values were estimated as being 0.03-0.76 (mean 0.36) for rice and 0.01-0.37 (mean 0.10 ) for water spinach. The integrated Hazard Quotient (HQi) is the summation of all food-specific HQs:

$$
\mathrm{HQi}=\mathrm{HQ}_{\text {rice }}+\mathrm{HQ}_{\mathrm{veg}}
$$




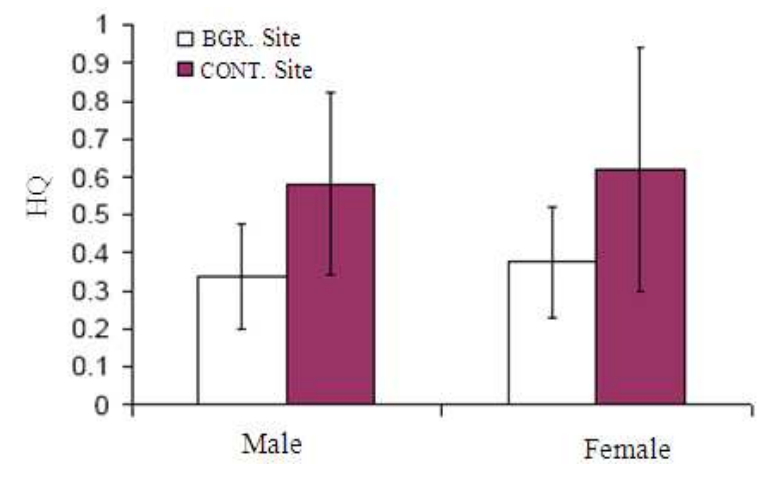

Fig. 2: Comparison of mean values of the hazard quotient index for rice by gender

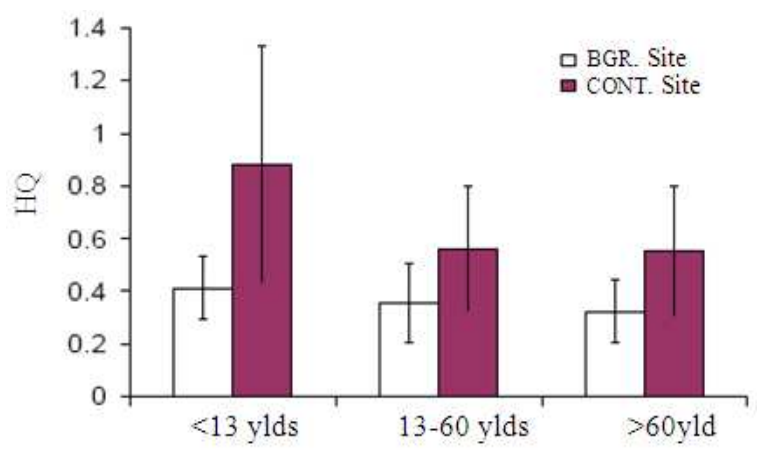

Fig. 3:Comparison of mean values of the hazard quotient index for rice by age group

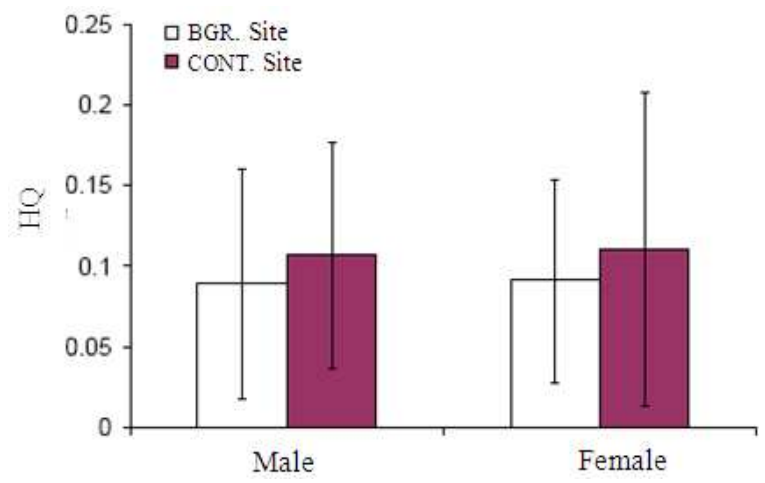

Fig. 4: Comparison of mean values of the hazard quotient index for vegetables by gender

HQi's index by age group was calculated by the equation recommended by USEPA (1997).

The integrated hazard quotient was classified by gender and age. Both males and females who ate rice had a hazard quotient below one in both study communities (Fig. 2).

However, it was substantially higher in the contaminated area and females are at a slightly higher risk than males.

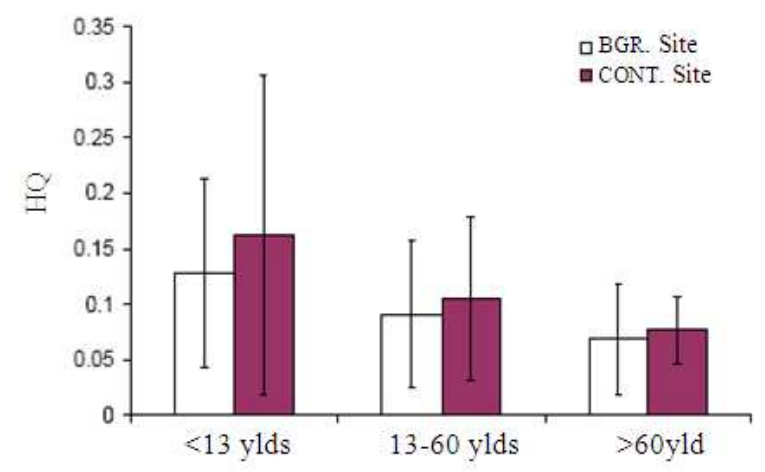

Fig. 5: Comparison of mean values of the hazard quotient index for vegetables by age

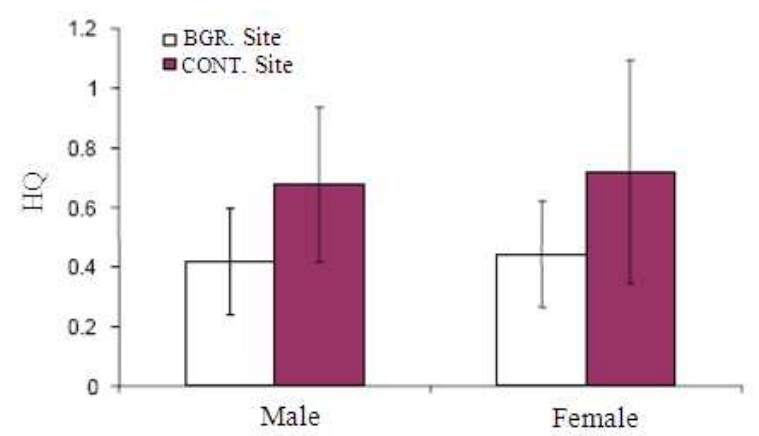

Fig. 6: Comparison of mean values of the integrated hazard quotient index for rice, vegetable by gender

The HQ index for males who ate rice was 0.34 in the reference area and 0.58 in the contaminated area and for females it was 0.37 in the reference area and 0.62 in the contaminated site. Males tended to consume more food than females but have higher body weight giving a lower HQ. HQ were $0.41-0.88$ for children below 13 years old, $0.36-0.56$ for individuals 13-60 years old and 0.32-0.55 for individuals above 60 (Fig. 3 and 4).

The HQ indexes were 0.089-0.091 in the reference area and 0.107-0.111 in the contaminated area.

Comparison between age groups, for vegetable: HQ indexes are significantly different between age groups. HQ indexes were $0.127-0.163$ for children $<13$ years old, 0.091-0.105 for individuals 13-60 years old and 0.068-0.077 for individuals above 60 years old (Fig. 5).

The integrated Hazard Quotient index (rice and vegetable, HQi) in Fig. 6 indicates that females have a slighty higher risk than males. There is a significant difference in integrated harzard quotient index between the reference and contaminated areas; 0.42 (males) and 0.44 (females) for individuals in the reference area and 0.68 (males) and 0.72 (females) for people in the contaminated area (Fig. 6). 
For children below 13 years old, the HQ is 0.50 in the reference area and 1.00 in the contaminated area. For adults, the HQ is $0.38-0.44$ in the reference area and 0.62-0.66 in the contaminated area (Fig. 6).

\section{DISCUSSON}

On the way to the river, wastewater often passes through agricultural fields and also flows over the field during heavy rain. The wastewater is also used to irrigate crops in the dry season, particularly paddy fields. The wastewater from the chemical and phosphate fertilizer factory in the canal outlet is highly acid.

Measured values of Chemical Oxygen Demand (COD) displayed a very large range $\left(10-61 \mathrm{mg} \mathrm{L}^{-1}\right.$, mean 27). The average measured vales of COD and BOD5 exceeded the acceptable level of the Vietnamese standard level A (COD $<6 \mathrm{mg} \mathrm{L}^{-1}$ and BOD $<4 \mathrm{mg}$ $\mathrm{L}^{-1}$ ). The majority of samples are lower than the Vietnam standard level a ( $\left.\geq 6 \mathrm{mg} \mathrm{L}^{-1}\right)(\mathrm{QCVN}, 2008 \mathrm{a})$.

Cation Exchangeable Capacity (CEC) in the soil suggested that there is a concentration gradient associated with distance from point sources of contamination.

Accumulation of of $\mathrm{Cu}, \mathrm{Zn}, \mathrm{As}$ and $\mathrm{Pb}$ in the soil exceeded the accepted limitation of the Vietnamese standards (QCVN, 2008b). Only concentrations of $\mathrm{Cd}$ were within Vietnamese limits. Mean concentrations of $\mathrm{Cu}, \mathrm{Zn}$ and $\mathrm{Pb}$ measured in the reference soils were within the limits of the Vietnamese standard. These data indicate that paddy soils adjacent to industrial areas are polluted by heavy metals. In the unpolished rice, those metals tend to be higher than that in rice grown in reference soils, particularly $\mathrm{Cd}$. Other studying on heavy metal contamination in soil and rice on the red river delta was given similary resuts (Vinh, 2004; Vinh and Minh, 2007a; 2007b).

Through the Average Daily Dose (ADD), consumption of rice and spinach of people living in two communes was not significantly different in the study. The Average Daily Dose (ADD; $\mathrm{mg} \mathrm{kg}^{-1} \mathrm{~d}$ ) of $\mathrm{Cd}$ may indicate that individuals living in the contaminated site have a greater risk of experiencing deleterious health effects associated with Cd compared to people living at the reference site.

Food-specific partial HQ:s for rice and spinach showed that people living contaminant area is sem to be higher risk athn that living in the reference area.

The HQ indices for consumption of water spinach indicate that there is no significant difference in health risk by gender, but age group was a significant risk factor. People who live in the reference area tended to be a lower risk group than those living in the contaminated area.

For HQi, children below the age of 13 have a higher index than adults, which is similar to the results obtained in previous studies and evaluations by the USEPA.

\section{CONCLUSION}

The accumulation of heavy metals from industrial waste has affected soil and water for a long time. People living in the contaminated area are at a greater risk for health issues than individuals in the reference area. Females are at somewhat higher risk than males and individuals below 13 years old are at a much higher risk than adults. It is important that the community, local authorities and other communities in similar situations are educated so a safer environment can be maintained in the future.

By the integrated hazard quotient, it was substantially higher in the contaminated area and females are at a slightly higher risk than males.

Children below the age of 13 had the highest potential health risk. No significant difference was seen between individuals who were between 13 and 60 years old and the group above 60 years old.

\section{ACKNOWLEDGMENT}

We would like to thank SAREC-SIDA for their strong financial support in implementing this study. We would also like to thank the local authorities, managers and farmers of the Thach Son commune, Lam Thao district.

\section{REFERENCES}

Hough, R.L., N. Breward, S.D. Young, N.M.J. Crout and A.M. Tye et al., 2004. Assessing potential risk of heavy metal exposure from consumption of home-produced vegetables by urban populations. Environ. Health, Perspect., 112: 215-221.

MONRE, 2006. The environment reports of vietnam 2005. Vietnam Ministry of Natural Resource and Environment, MONRE.

QCVN, 2008a. National technical regulation on surface water quality. Vietnam Ministry of Natural Resource and Environment.

QCVN, 2008b. National technical regulation on soil quality. Vietnam Ministry of Natural Resource and Environment.

Rayment, G.E. and F.R. Higginson, 1992. Australian Laboratory Handbook of Soil and Water Chemical Methods. 1st Edn., Inkata Press, Melbourne, ISBN10: 0909605688, pp: 330. 
Stevens, D., M. Smart, G. Cozens, B. Zarcinas and G. Barry et al., 2003. Csiro Land and Water's methods manual. ACIAR and CSIRO Land and Water.

USEPA, 1989. Risk Assessment Guidance for Superfund: Interim Final. 1st Edn., Environmental Protection Agency, Washington.

USEPA, 1997. Risk assessment guidance for superfund. United States Environmental Protection Agency Press.

Vinh, N.C. and N.D. Minh, 2007a. Affecting of contamination from trade villages on the accumulation of Cadmic (Cd) and Zink ( $\mathrm{Zn})$ in soil and rice in red river delta. J. Soil Sci., 27: 103-110.
Vinh, N.C. and N.D. Minh, 2007b. The affect of contamination of heavy metals $(\mathrm{Cd}, \mathrm{Zn}, \mathrm{Cu}, \mathrm{Pb})$ in soil and rice form trade villages on red river delta. J. Soil sci., 27: 103-110.

Vinh, N.C., 2004. Potential risks of the environmental contamination from fertilization and industrial waste in urban areas in rice-based agricultural systems in Vietnam. Proceedings of the Workshop on the Development of Effective Management and Decision-making Tools for the Mitigation of Contamination of Soils, Crops and Water in the Greater Mekong Sub Region, Jun. 16-18, Thailand. 